\title{
Depth to Basement and Thickness of Unconsolidated Sediments for the Western United States-Initial Estimates for Layers of the U.S. Geological Survey National Crustal Model
}

Open-File Report 2018-1115 


\section{Depth to Basement and Thickness of Unconsolidated Sediments for the Western United States - Initial Estimates for Layers of the U.S. Geological Survey National Crustal Model}

By Anjana K. Shah and Oliver S. Boyd

Open-File Report 2018-1115 


\title{
U.S. Department of the Interior \\ RYAN K. ZINKE, Secretary
}

\author{
U.S. Geological Survey \\ James F. Reilly II, Director
}

U.S. Geological Survey, Reston, Virginia: 2018

For more information on the USGS - the Federal source for science about the Earth, its natural and living resources, natural hazards, and the environment-visit https://www.usgs.gov or call 1-888-ASK-USGS.

For an overview of USGS information products, including maps, imagery, and publications,

visit https://store.usgs.gov.

Any use of trade, firm, or product names is for descriptive purposes only and does not imply endorsement by the U.S. Government.

Although this information product, for the most part, is in the public domain, it also may contain copyrighted materials as noted in the text. Permission to reproduce copyrighted items must be secured from the copyright owner.

Suggested citation:

Shah, A.K, and Boyd, O.S., 2018, Depth to basement and thickness of unconsolidated sediments for the western United States_-Initial estimates for layers of the U.S. Geological Survey National Crustal Model: U.S. Geological Survey Open-File Report 2018-1115, 13 p., https://doi.org/10.3133/ofr20181115.

ISSN 2331-1258 (online) 


\section{Contents}

Abstract

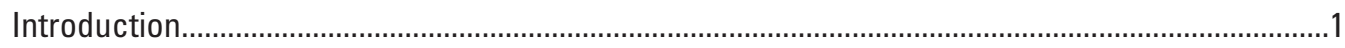

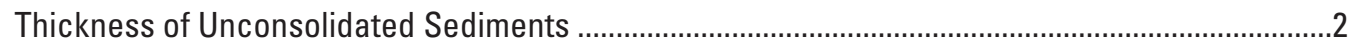

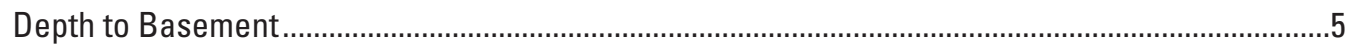

Available Data Files

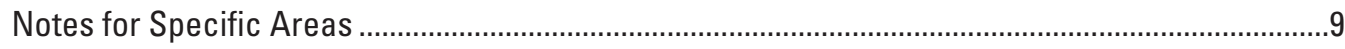

The Basin and Range in Arizona, California, Idaho, Montana, Nevada, New Mexico,

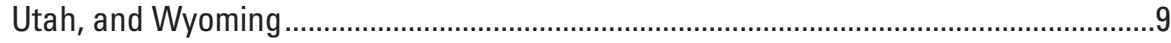

Central Valley of California ...................................................................................................10

Glacial Deposits East of the Rocky Mountains-Montana, North Dakota, and

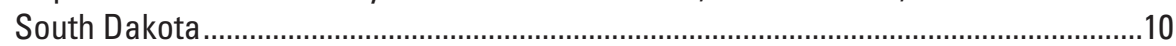

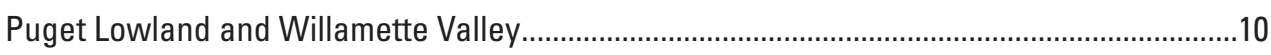

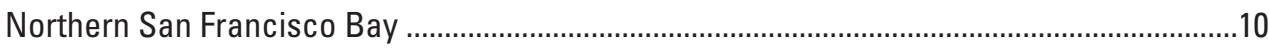

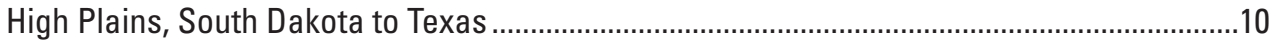

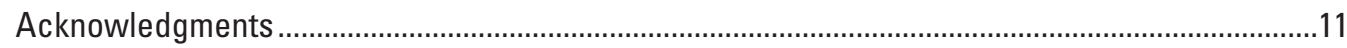

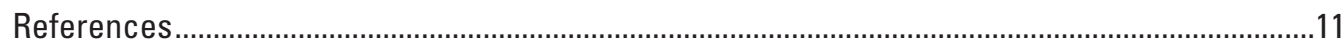

\section{Figures}

1. Thickness of unconsolidated sediments modeled by Pelletier and others (2016)............2

2. Thickness of unconsolidated sediments combined from Pelletier and others (2016) and regional models ........................................................................................................

3. Previous models of depth to basement.......................................................................6

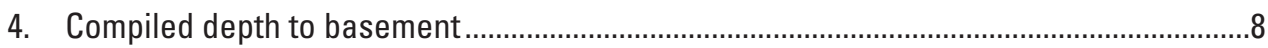

\section{Tables}

1. Regional models used in the thickness of unconsolidated sediments layer.....................3

2. Regional models used in the depth to basement layer ....................................................

3. Density structure used for gravity modeling in the Basin and Range Province ................9 


\section{Conversion Factors}

International System of Units to U.S. customary units

\begin{tabular}{lll}
\hline \multicolumn{1}{c}{ Multiply } & \multicolumn{1}{c}{ By } & \multicolumn{1}{c}{ To obtain } \\
\hline & Length & \\
\hline meter $(\mathrm{m})$ & 3.281 & foot $(\mathrm{ft})$ \\
kilometer $(\mathrm{km})$ & 0.6214 & mile $(\mathrm{mi})$ \\
kilometer $(\mathrm{km})$ & 0.5400 & mile, nautical $(\mathrm{nmi})$ \\
meter $(\mathrm{m})$ & 1.094 & yard $(\mathrm{yd})$ \\
\hline & Density & \\
\hline gram per cubic centimeter $\left(\mathrm{g} / \mathrm{cm}^{3}\right)$ & 62.4220 & pound per cubic foot $\left(\mathrm{lb} / \mathrm{ft}^{3}\right)$ \\
\hline
\end{tabular}




\title{
Depth to Basement and Thickness of Unconsolidated Sediments for the Western United States-Initial Estimates for Layers of the U.S. Geological Survey National Crustal Model
}

\author{
By Anjana K. Shah and Oliver S. Boyd
}

\begin{abstract}
We present numeric grids containing estimates of the thickness of unconsolidated sediments and depth to the pre-Cenozoic basement for the western United States. Values for these grids were combined and integrated from previous studies or derived directly from gravity analyses. The grids are provided with 1-kilometer grid-node spacing in ScienceBase (https://www.sciencebase.gov). These layers may be updated as results from new studies become available.
\end{abstract}

\section{Introduction}

The U.S. Geological Survey (USGS) is currently (2018) developing a National Crustal Model (Boyd and Shah, 2018) to assist with earthquake hazard risk assessment by supporting estimates of ground shaking in response to an earthquake. The period-dependent intensity and duration of shaking depend upon the three-dimensional seismic velocity, seismic attenuation, and density distribution of an area, which in turn are governed to a large degree by rock type. For example, ground composed of poorly consolidated sediments typically experiences greater shaking intensity than ground composed of bedrock such as granite or sandstone. Additionally, ground shaking within sedimentary basins may be of greater duration and amplitude relative to locations outside of basins. In order to estimate the three-dimensional geophysical structure, knowledge of surface and subsurface geologic variations is needed. Geological data and models from various sources are thus being compiled to determine geophysical property variations over the conterminous United States, with 1-kilometer $(\mathrm{km})$ grid-node spacing.

Two quantities describing vertical dimensions of key geologic layers provide a spatial framework for describing threedimensional geophysical structure: (1) the thickness of unconsolidated sediments (which may also be considered as the depth to bedrock) and (2) the depth to basement. The dimensions of these layers determine where strong impedance contrasts are likely to occur and are therefore important for seismic hazard assessment. Estimates of these quantities also play important roles in other fields such as water resources, mineral and energy resources, and three-dimensional geologic mapping.

Models of these quantities for the western conterminous United States, with 1-km grid-node spacing, are presented here. The grid values have mostly been combined and integrated from previous published models, which typically cover smaller areas. These published grids were derived using various methods including seismic reflection, well data, gravity, and magnetic surveys; many include a component of interpretation. We also used gravity data to generate new estimates in some areas where previous models were not available.

Large areas of the grids are based on models derived from quantities such as topography or gravity data, and there are likely to be deviations from the actual values being estimated; some deviations may be large. Additionally, there can be unusual "edge effects" where estimates from different sources are merged. The grids are thus intended as approximations over a broad scale; studies that require more precise estimates should include additional data such as well logs, seismic reflection, or other data available at local scales. Efforts to develop improved models of unconsolidated sediment thickness and depth to basement at various scales are ongoing within the scientific community. A goal of the National Crustal Model is to continue to update layer grids as new models become available. 


\section{Thickness of Unconsolidated Sediments}

The surficial layer of unconsolidated sediments can generally be thought of as sedimentary deposits that have not yet lithified into sedimentary rock. In some areas, unconsolidated sediments lie directly over igneous or metamorphic rock, so describing their thickness is straightforward. In other areas, the sediments may gradually become more indurated with depth, so a distinct boundary between sediments and sedimentary rock is more difficult to define. One approach is to define unconsolidated sediments according to age, as this can provide a consistent definition in all locales. A recent study covering the conterminous United States (Pelletier and others, 2016) defined unconsolidated sediments as those of Miocene age or younger; this definition is similar to that used for other hydrologic studies (for example, Gutentag and others, 1984).

To estimate the thickness of unconsolidated sediments, we used the model of combined sediment and soil thickness derived by Pelletier and others (2016) as a starting grid. For that model, surface geologic data and topographic analyses were combined to determine whether an area was likely to experience net erosion (highland hillslopes) or net sediment accumulation (lowland areas and highland valleys). The latter generally represents younger basins and river valleys. Within these divisions, they combined additional topographic analyses and well data to estimate the thickness of unconsolidated sediments (fig. 1). Pelletier and others (2016) acknowledge, however, that the methods do not work well in glaciated areas or in areas where sediments are likely to be greater than 50 meters (m) thick, and thus they capped the sediment thickness at $50 \mathrm{~m}$ in all areas. This cap can be a substantial underestimate in various places, especially in sedimentary basins.

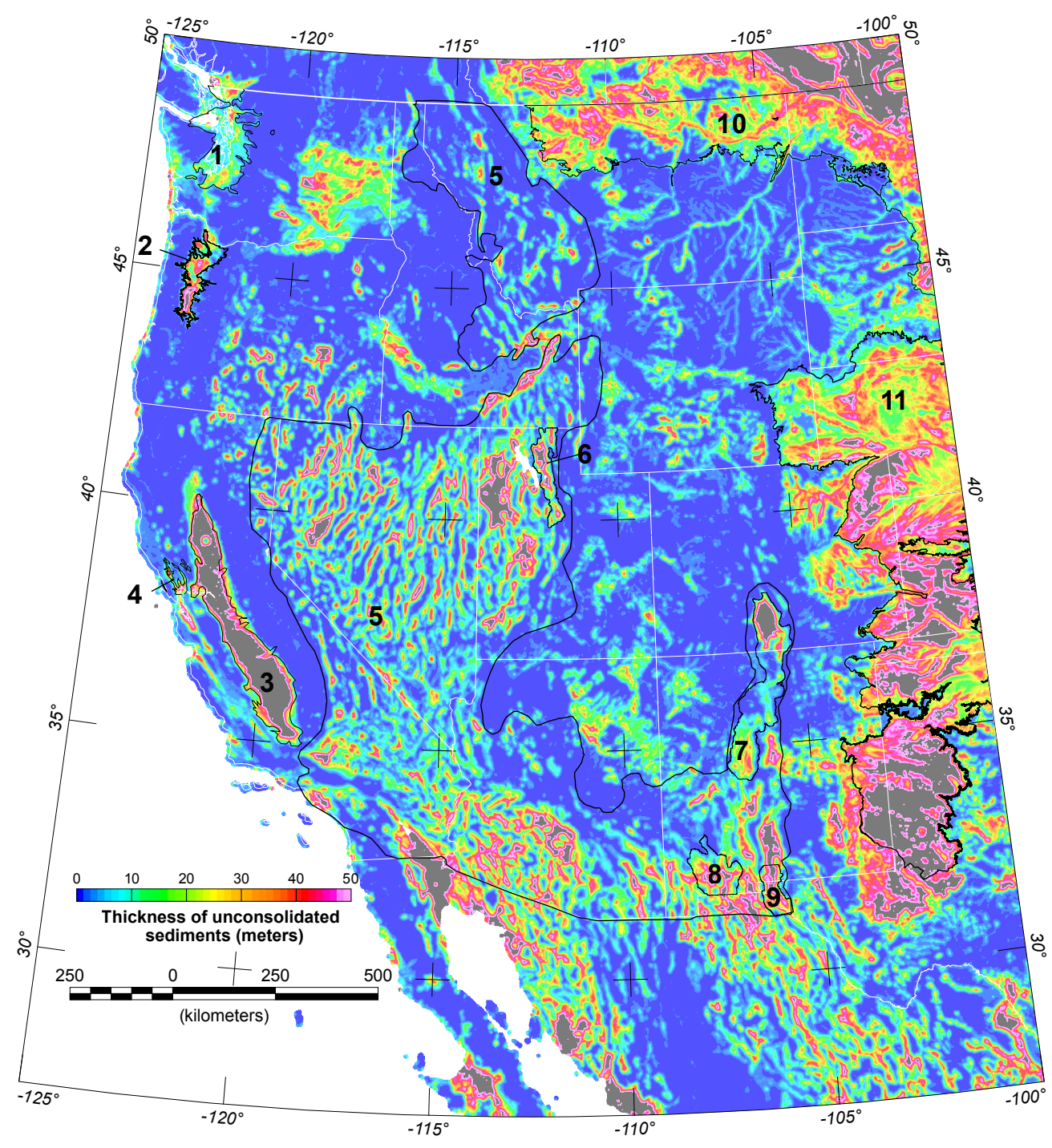

Figure 1. Thickness of unconsolidated sediments modeled by Pelletier and others (2016), with areas assigned a maximum value of 50 meters shaded in gray. For these areas, the actual thickness is likely to be greater. Polygons show bounds of regional models that were merged with the Pelletier and others (2016) model-1, Puget Sound; 2, Portland and Willamette Basins; 3, Central Valley of California; 4, northern San Francisco Bay; 5, Basin and Range; 6, Salt Lake Valley; 7 , San Luis and Albuquerque Basins; 8, Mimbres Basin; 9, Hueco Bolson; 10, glacial deposits east of the Rocky Mountains; 11, High Plains sediments. White lines represent State boundaries. 
Alternative sediment thickness estimates are required in locales where bedrock is likely to be deeper than $50 \mathrm{~m}$. We thus incorporated local estimates of sediment thickness based on other methods, mostly from previous studies. These estimates (summarized in table 1 and shown in figure 2) include forearc basins, rift basins, and areas with high amounts of glacial and eolian deposits. In many of those areas, the local models and the Pelletier and others (2016) model are merged smoothly (such as the High Plains), but in some areas there are sharp contrasts between the different models (such as California's Central Valley and the San Luis and Albuquerque Basins). Potential future versions of this layer would include reassessment in these areas using additional data constraints. For some of the smaller (usually a few kilometers wide) areas such as fluvial valleys where Pelletier and others (2016) capped sediment thicknesses at $50 \mathrm{~m}$, estimates from other studies were not available. We estimated the sediment thickness in these areas by first removing values of $50 \mathrm{~m}$ from the grid and then fitting a smoothly varying surface to those areas. The surface was determined by finding a minimum curvature surface that matches grid values less than $50 \mathrm{~m}$. This approach essentially ensures smooth topographic slopes for the sediment-thickness grid over these valleys and small basins.

For the Basin and Range region, gravity modeling was used to estimate sediment thickness within the numerous smaller basins associated with Cenozoic extension. We employed the separation approach of Jachens and Moring (1990), which uses an iterative algorithm to separate gravity anomalies caused by lower density sedimentary fill from those caused by density variations within the surrounding rock. The basin-fill gravity anomalies are then used to solve for the thickness of the fill layer, assuming a prescribed layered density structure. The approach is discussed in more detail in the section "Notes for Specific Areas."

For some areas, such as eastern Washington (which has hundreds of meters of eolian sediment) and larger basins of New Mexico and Colorado (including the San Juan, Denver, and Raton Basins), our model is especially generalized, and the sediment thickness is likely to be underestimated. Updated sediment-thickness estimates will be incorporated into the model as additional data or models become available.

Table 1. Regional models used in the thickness of unconsolidated sediments layer.

[Area indexes used in figures 1 and 2]

\begin{tabular}{|c|c|c|c|}
\hline $\begin{array}{l}\text { Area } \\
\text { index }\end{array}$ & Location & Model source & Method \\
\hline 1 & Puget Sound, Washington & Eungard (2014) & Mixed \\
\hline 3 & Central Valley, California & Williamson and others (1989) & Wells \\
\hline 4 & Northern San Francisco Bay, California & Modified from Langenheim and others (2010) & Gravity \\
\hline 6 & Salt Lake Valley, Utah & Radkins and others (1989) & Mixed \\
\hline 7 & $\begin{array}{l}\text { San Luis and Albuquerque Basins, Colorado and } \\
\text { New Mexico }\end{array}$ & Keller and others (1984), Grauch and Connell (2013) & Gravity, wells \\
\hline 8 & Mimbres Basin, New Mexico and Texas & Heywood (2002) & Gravity, wells \\
\hline 11 & $\begin{array}{l}\text { High Plains: Colorado, Kansas, Nebraska, New } \\
\text { Mexico, Oklahoma, South Dakota, Texas }\end{array}$ & $\begin{array}{l}\text { Gutentag and others (1984), Cedarstrand and Becker (1998), } \\
\text { Houston and others (2013) }\end{array}$ & Mixed \\
\hline 12 & $\begin{array}{l}\text { Offshore areas in San Francisco Bay, the Colum- } \\
\text { bia River, and Puget Sound }\end{array}$ & Whittaker and others (2013) & Mixed \\
\hline
\end{tabular}




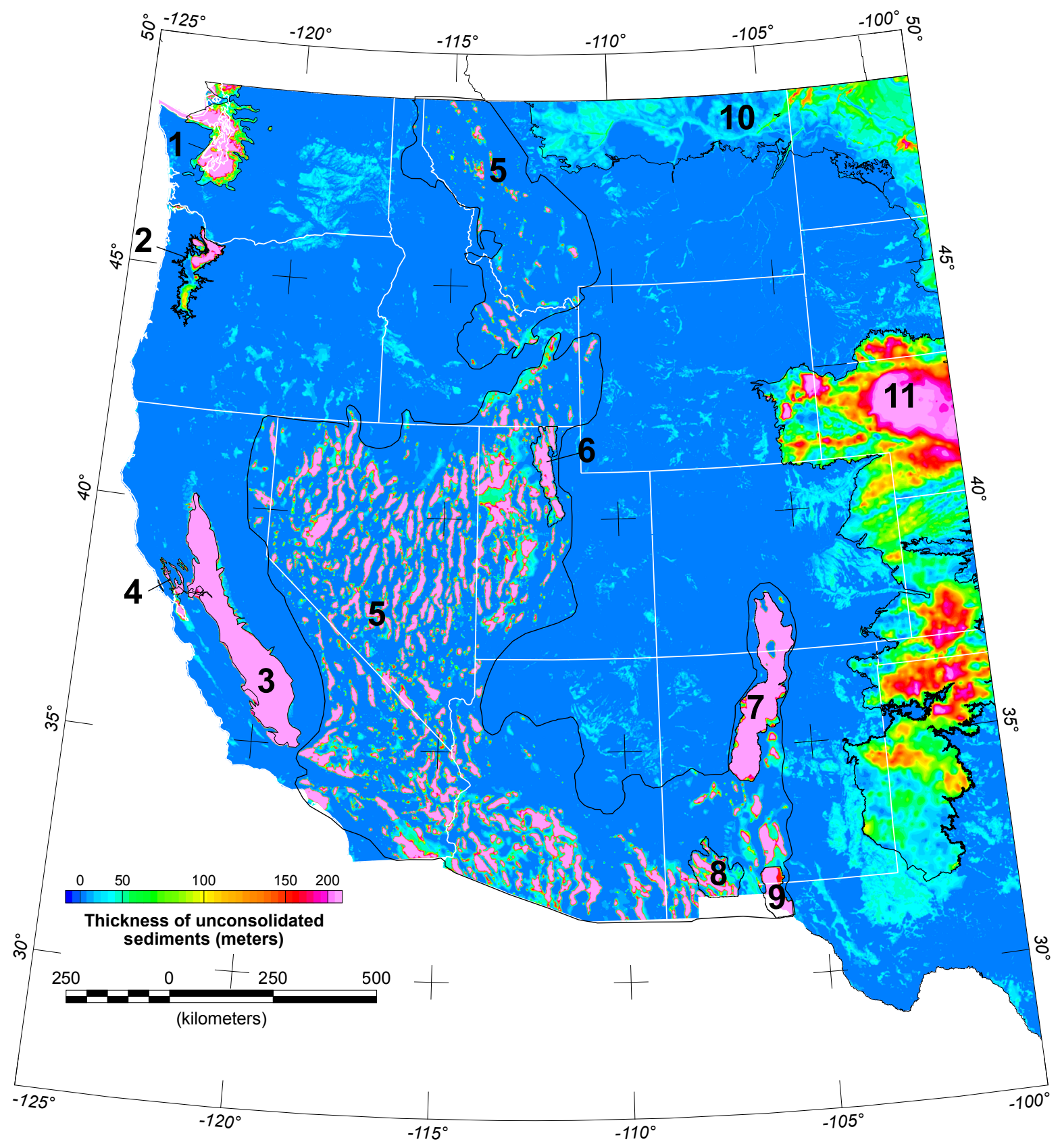

Figure 2. Thickness of unconsolidated sediments combined from Pelletier and others (2016) and regional models. Note that the color scale is different than that used in figure 1. Polygons show bounds of regional models-1, Puget Sound; 2, Portland and Willamette Basins; 3, Central Valley of California; 4, northern San Francisco Bay; 5, Basin and Range; 6, Salt Lake Valley; 7, San Luis and Albuquerque Basins; 8, Mimbres Basin; 9, Hueco Bolson; 10, glacial deposits east of the Rocky Mountains; 11, High Plains. White lines represent State boundaries. 


\section{Depth to Basement}

The depth to basement (sometimes referred to as the depth to crystalline basement) is typically defined as the depth to the top surface of igneous or metamorphic rocks; rocks above this depth are either sediments or sedimentary rocks. Impedance contrasts are often observed at the interface between these rock types. To provide consistency over different regions, it is helpful to describe the basement rocks in terms of their geologic age. This approach is most directly achieved in the North American midcontinent, where the Great Unconformity distinguishes Precambrian basement from sedimentary cover (Marshak and others, 2017, and references therein). However, challenges arise in the western United States because tectonic processes have created significant local variations in the elevation of this surface (Marshak and others, 2017). Precambrian rocks crop out as far west as California, but there is limited information regarding their broader distribution. Furthermore, Cenozoic tectonic events have generated more recently formed basins. Numerous studies of basement elevation in areas west of the Rocky Mountains thus concern the thickness of overlying Cenozoic sedimentary rock.

Early published maps of sedimentary rock thickness or depth to basement for the conterminous United States were provided by Frezon and others (1983) and Exxon Production Research Company (1985). These maps combined public and proprietary data, and data sources were not provided. Nonetheless, these maps provide a rare quantitative estimate of depth to basement over the conterminous United States. The maps are very similar and may have been derived from the same datasets. Mooney and Kaban (2010) combined the Frezon and others (1983) map with other studies over California's Central Valley and the State of Nevada to provide an updated grid (fig. $3 A$ ). Additional published data over the midcontinent (between the Rocky Mountains and Appalachian Mountains) were later compiled by Marshak and others (2017), who provided an update for the depth to Precambrian basement within that region (fig. $3 B$ ).

For the western United States, we considered the depth to Mesozoic basement but cropped the resulting grid to the east along a boundary that approximates the extent of the Basin and Range Province to the south and areas with similar deformation to the north (fig. 4). We used the grid derived by Mooney and Kaban (2010) as a base map and incorporated previous local models for deeper valleys, summarized in table 2 . In some areas, however, sediments or sedimentary rocks are present at the surface but the depth to basement given by Mooney and Kaban (2010) is zero, and alternative models were not available. We thus adjusted the depth to basement so that it is at least as deep as the depth to bedrock at each grid node. In some areas, Miocene or younger sediments unconformably lie over older crystalline rock, so this adjustment may be a good approximation, but in others, that is not the case, and the depth to basement is underestimated. One example might be in eastern Washington and parts of Oregon, where there are thick layers of sedimentary rocks beneath Miocene lava flows (Saltus, 1993). For areas farther east, the depth to Precambrian basement compiled by Marshak and others (2017) is used in the National Crustal Model.

The use of basement depth for estimation of geophysical characteristics such as density or velocity presents several challenges. One issue is that, for very deep basins, the definition of basement can be ambiguous because deep sedimentary rocks may experience low-grade metamorphism. In these cases, the depth to basement is usually considered to be the depth to igneous or metamorphic rock that existed prior to sedimentary deposition, but the differences in velocity and density between the basement and overlying metasedimentary rock may be small. Another issue that may arise is the presence of carbonate rocks, which may also be similar in density and velocity to igneous or metamorphic basement rocks. In these situations, consideration of the lithology of the corresponding layers is required. 


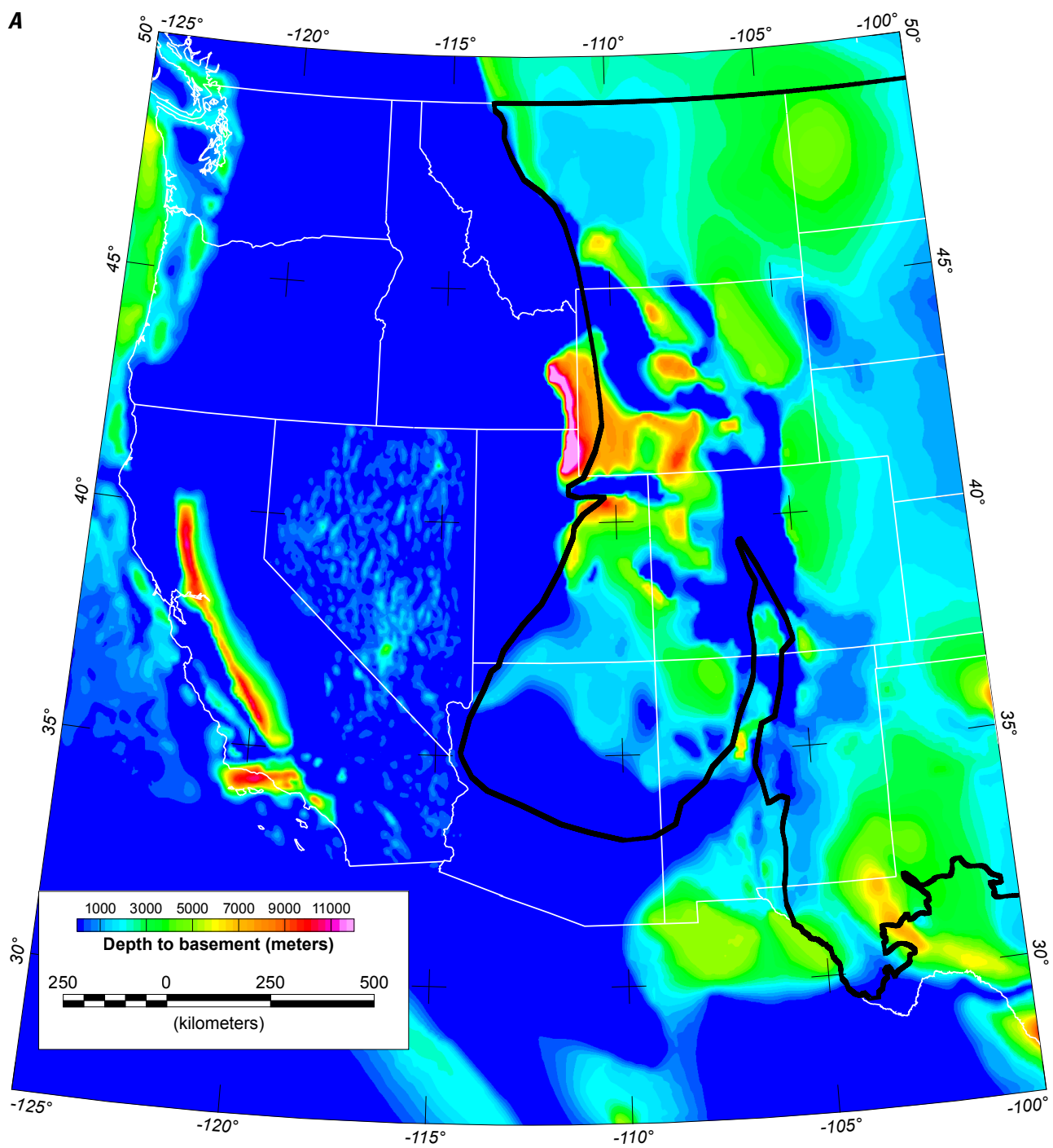

Figure 3. Previous models of depth to basement. $A$, Sediment thickness compiled by Mooney and Kaban (2010). Solid black line shows the outline of the grid derived by Marshak and others (2017). $B$, Depth to Precambrian basement calculated using the basement elevation model of Marshak and others (2017) and the SRTM30 digital elevation model of Becker and Sandwell (2011). 


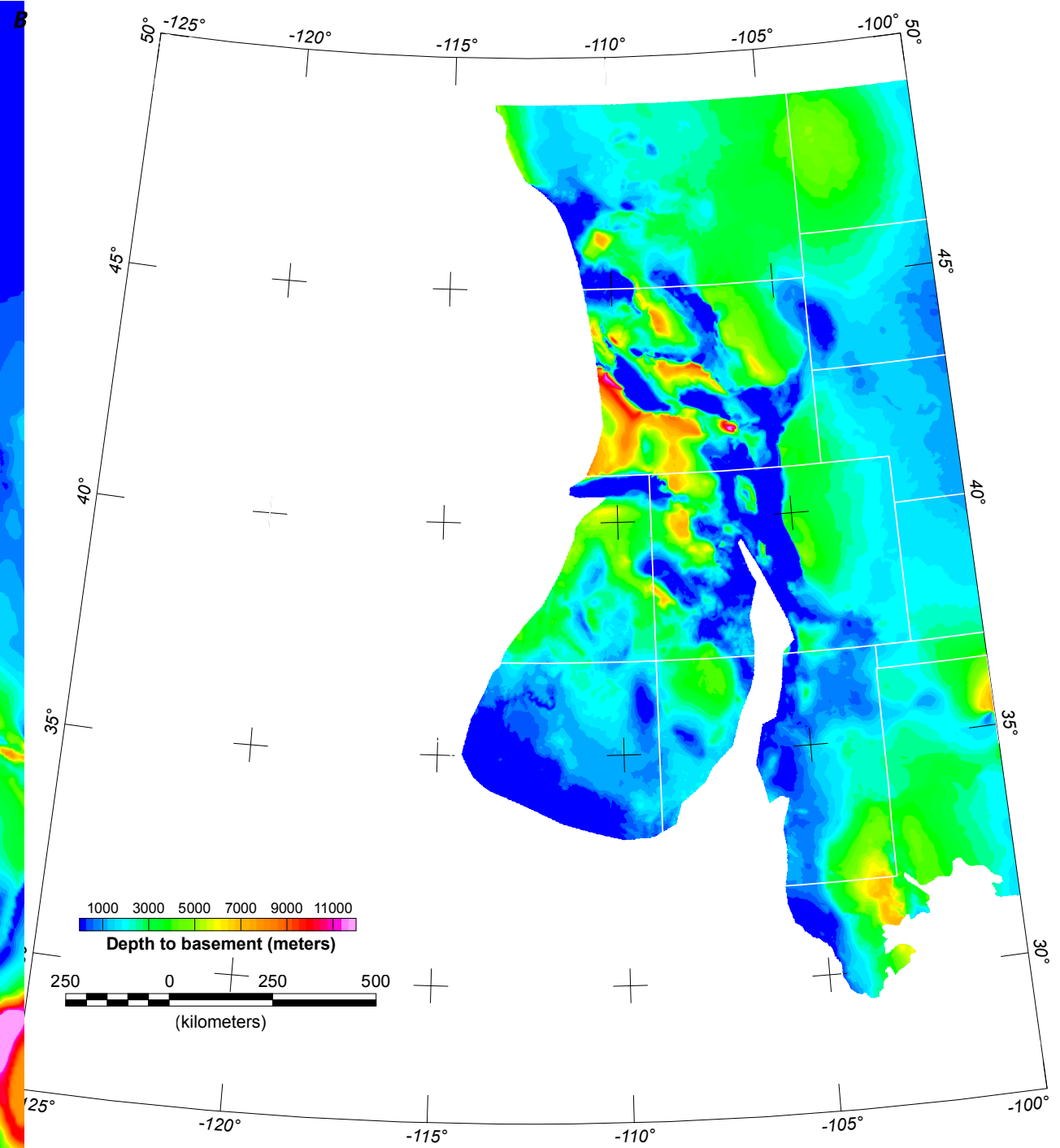

Figure 3. Previous models of depth to basement. $A$, Sediment thickness compiled by Mooney and Kaban (2010). Solid black line shows the outline of the grid derived by Marshak and others (2017). $B$, Depth to Precambrian basement calculated using the basement elevation model of Marshak and others (2017) and the SRTM30 digital elevation model of Becker and Sandwell (2011).-Continued 


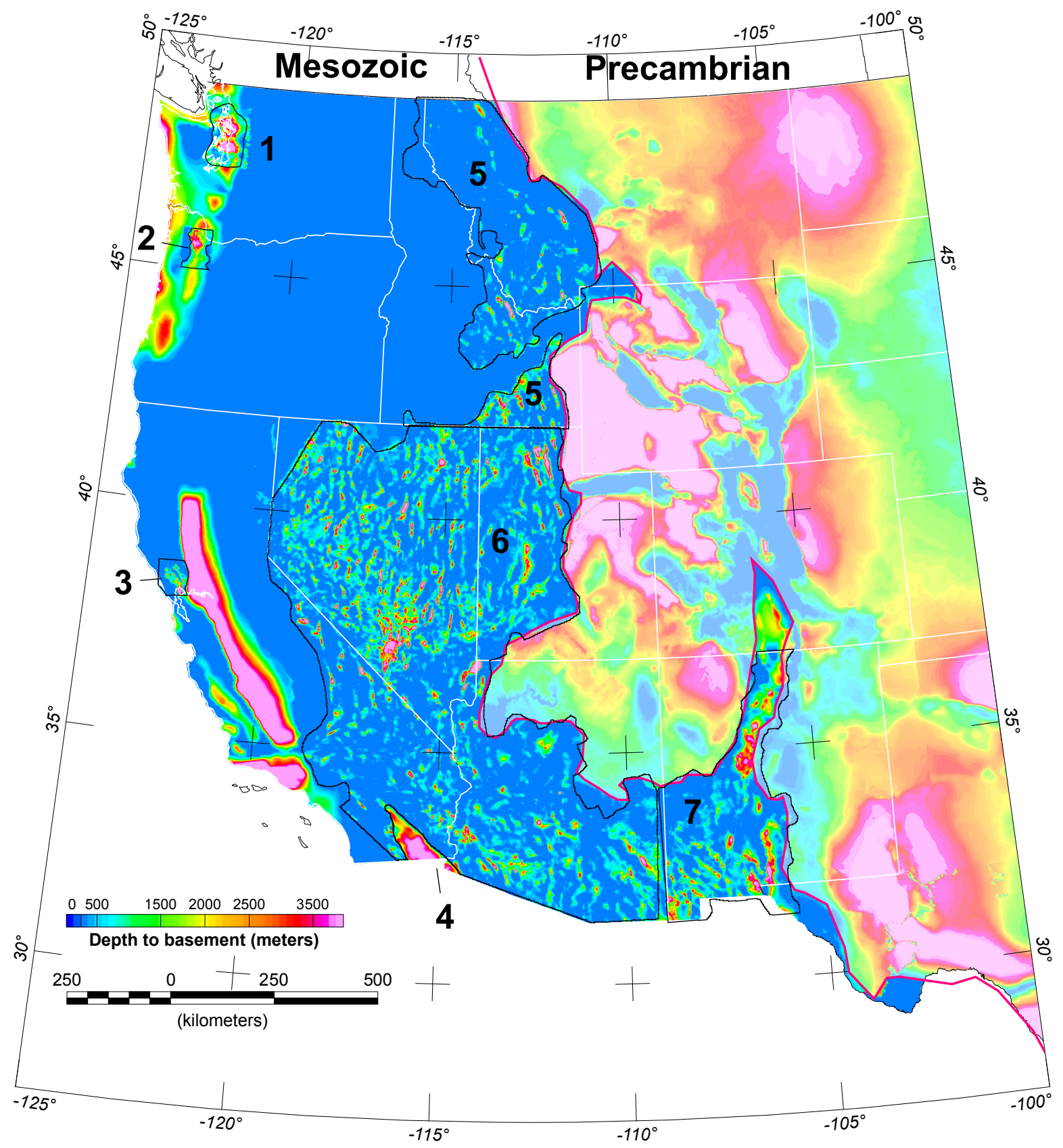

Figure 4. Compiled depth to basement. Polygons show bounds of regional models-1, Puget Sound; 2, Tualatin basin; 3, northern San Francisco Bay; 4, Salton Trough; 5, Basin and Range of Idaho and Montana; 6, Basin and Range of Arizona, California, Nevada, and Utah; 7, Basin and Range of New Mexico. Pink line marks eastern boundary of the depth to Mesozoic basement grid (this study); values north or east of this line represent the depth to Precambrian rock (Marshak and others, 2017). White lines represent State boundaries. 
Table 2. Regional models used in the depth to basement layer.

[Area indexes used in figure 4]

\begin{tabular}{|c|c|c|c|}
\hline $\begin{array}{c}\text { Area } \\
\text { index }\end{array}$ & Location & Reference & Method \\
\hline 1 & Puget Sound, Washington & Brocher and others (2001) & Gravity \\
\hline 3 & Northern San Francisco Bay, California & Langenheim and others (2010) & Gravity \\
\hline 4 & Salton Trough, California & Lovely and others (2006) & Gravity \\
\hline 6 & Basin and Range of Arizona, California, Nevada, and Utah & Saltus and Jachens (1995) & Gravity \\
\hline 7 & Basin and Range, New Mexico & This study; Shah and others (2018) & Gravity \\
\hline
\end{tabular}

\section{Available Data Files}

Grid data for this portion of the National Crustal Model are provided in comma-separated text files, which may be downloaded freely (Shah and Boyd, 2018; Shah and others, 2018). All layers are defined relative to the land surface. The grids cover the western United States from the west coast to longitude $100^{\circ} \mathrm{E}$ for the thickness of unconsolidated sediments and to the boundary shown in figure 4 for the depth to Mesozoic basement. Future work may include updates of the grids, as new local models describing these layers become available, and extension of these grids to include the full conterminous United States.

\section{Notes for Specific Areas}

\section{The Basin and Range in Arizona, California, Idaho, Montana, Nevada, New Mexico, Utah, and Wyoming}

Previous models using the Jachens and Moring (1990) gravity separation approach were developed to estimate the depth to basement for a subset of the Basin and Range Province in Nevada, Arizona, Utah, and California (Saltus and Jachens, 1995). This approach was used to extend these models to areas showing similar extensional features in New Mexico, Idaho, and Montana using the same layered density structure as Saltus and Jachens (1995). State geologic maps (Luddington and others, 2007; Stoeser and others, 2007) were used to define areas where Cenozoic sediments are present at the surface. Gravity data by McCafferty and others (1998) and National Oceanic and Atmospheric Administration (1998) were used to constrain the models.

To estimate depth to bedrock, we applied the separation approach to find the thickness of Miocene and younger sediments rather than Cenozoic sediments and to cover a wider area that also includes New Mexico, Idaho, Montana, and a small part of Wyoming. We used the same density structure as Saltus and Jachens (1995) (table 3), which is based on well data. However, because only the upper two layers have density contrasts large enough to represent unconsolidated sediments, we capped the sediment thickness at $600 \mathrm{~m}$. Deeper model layers are assumed to represent sedimentary bedrock. Additionally, the algorithm assigns a sediment thickness of zero to areas outside of the basin fill (in this study, rocks that are older than Miocene age). This approach is different from that of Pelletier and others (2016), who included both soil and sedimentary deposits. We thus combined the gravity model with the Pelletier and others (2016) model by comparing the two thickness estimates at each grid node and using the larger of the two. This method provides nonzero sediment thickness values over much of the region and effectively smooths the models near the edges of the basin fill.

Data used as inputs to the depth to bedrock gravity model include an isostatic residual gravity anomaly, which was calculated from public gravity-station data (University of Texas at El Paso Regional Geospatial Service Center, 2016) assuming a density contrast of 0.5 grams per cubic centimeter $\left(\mathrm{g} / \mathrm{cm}^{3}\right)$ at the Moho and using the method of Simpson and others (1986). The boundaries of Miocene fill areas were derived from USGS

Table 3. Density structure used for gravity modeling in the Basin and Range Province (after Saltus and Jachens, 1995).

[m, meter; $\mathrm{g} / \mathrm{cm}^{3}$, gram per cubic centimeter]

\begin{tabular}{cc}
\hline Depth $(\mathbf{m})$ & Density contrast $\mathbf{( g / \mathbf { c m } ^ { 3 } )}$ \\
\hline $0-200$ & -0.65 \\
$200-600$ & -0.55 \\
$600-1,200$ & -0.35 \\
$>1,200$ & -0.25 \\
\hline
\end{tabular}


State geologic map compilations (Luddington and others, 2007; Stoeser and others, 2007). The SRTM30_Plus digital elevation map (Becker and Sandwell, 2011) was used to estimate surface topography.

The depth to bedrock gravity model includes estimates in subareas from previous, more detailed studies, including the Salt Lake Valley, Mimbres Basin, Hueco Bolson, and San Luis and Albuquerque Basins (see table 1). Estimates from those studies supersede the gravity model estimates.

\section{Central Valley of California}

An estimate for post-Eocene sediment thickness developed by Williamson and others (1989) was used for the thickness of unconsolidated sediments in California's Central Valley. This package of sediment consists of Miocene and younger sediments over most of the valley because Oligocene deposition was limited mostly to the southern San Joaquin Valley (Bertoldi and others, 1991). The map provided by Williamson and others (1989) was digitized by Faunt (2009). The area covered by this map is larger than the area described as Miocene or younger in State geologic maps (Luddington and others, 2007), so it was trimmed to match the maps of surface geology.

\section{Glacial Deposits East of the Rocky Mountains-Montana, North Dakota, and South Dakota}

The grid of glacial deposits by Soller and Garrity (2018) primarily describes Quaternary deposits, which is different from the definition of unconsolidated sediments used here. Additionally, zero values are assigned to various areas without glacial deposits. To include sediments of Miocene age or younger, as well as soil deposits, the maximum value between the Soller and Garrity (2018) and Pelletier and others (2016) grids was used.

\section{Puget Lowland and Willamette Valley}

Both the Puget Lowland and Willamette Valley are underlain by volcanic rocks ranging in age from Miocene to Holocene. The thickness of unconsolidated sediments refers to sediments above volcanic layers. Additionally, in the Puget Lowland, Eungard (2014) defined unconsolidated sediments as younger than Miocene. The definition for this region therefore differs slightly from that used elsewhere.

\section{Northern San Francisco Bay}

Langenheim and others (2010) generated a model of depth to Cenozoic basement for a region north of the San Francisco Bay; this model is incorporated in our grid of depth to basement. We modified this model to also provide estimates of sediment thickness. The model was trimmed so that only areas where Miocene or younger sediments are present at the surface were used; other parts of this region were assigned the sediment thickness derived by Pelletier and others (2016). Additionally, the model uses a layered density function such that material in the upper $300 \mathrm{~m}$ has a density contrast with the basement closest to that of sediments $\left(0.48 \mathrm{~g} / \mathrm{cm}^{3}\right)$, whereas deeper layers have densities more similar to that of sedimentary rock $\left(<0.32 \mathrm{~g} / \mathrm{cm}^{3}\right)$. The thickness of the sediment layers was therefore capped at $300 \mathrm{~m}$.

\section{High Plains, South Dakota to Texas}

In the northern High Plains, well data providing the depth of Miocene layers were available for South Dakota and northern Kansas (Houston and others, 2013), so these data were used. For the rest of the region, the maps presented by Gutentag and others (1984) and digitized by Cedarstrand and Becker (1998) were used. 


\section{Acknowledgments}

We are grateful to a number of scientists who provided grids of depth to basement or thickness of unconsolidated sediments for various study areas. These include R. Blakely, B. Drenth, V.J.S. Grauch, N. Herrera, C. Heywood, V. Langenheim, D. McPhee, W. Mooney, and D. Soller. The depth to basement models over the Basin and Range within New Mexico were calculated by V. Langenheim and J. Glen; those within Idaho and Montana were calculated by R. Jachens. We thank J. Phillips for providing code to calculate depth to basement using the Jachens and Moring method for the thickness of unconsolidated sediments grids. D. Soller and J. Phillips provided helpful reviews that improved the text. This effort was funded by the U.S. Geological Survey Earthquake Hazards Program.

\section{References}

Becker, J.J., and Sandwell, D.T., 2011, SRTM30_PLUS—Data fusion of SRTM land topography with measured and estimated seafloor topography (ver. 7, February 2, 2012): Scripps Institution of Oceanography, accessed February 2018 through Oasis Montaj software by Geosoft, Inc.

Bertoldi, G.L., Johnston, R.H., and Evenson, K.D., 1991, Ground water in the Central Valley, California—A summary report: U.S. Geological Survey Professional Paper 1401-A, 44 p.

Boyd, O., and Shah, A.K., 2018, National 3D geology—Building a USGS National Crustal Model—Theoretical foundation, inputs, and calibration, in Thorleifson, L.H., ed., Geologic Mapping Forum 2018 abstracts-Minneapolis, Minn., March 27-29, 2018: Minnesota Geological Survey Open File Report OFR-18-1, p. 13-14. [Also available at http://hdl.handle.net/11299/194852.]

Brocher, T.M., Parsons, T., Blakely, R.J., Fisher, M.A., Wells, R.E., and Christensen, N.I., 2001, Upper crustal structure in Puget Lowland, Washington-Results from the 1998 seismic hazards investigation in Puget Sound: Journal of Geophysical Research, v. 106, no. B7, p. 13541-13564.

Cederstrand, J.R., and Becker, M.F., 1998, Digital map of base of aquifer for High Plains Aquifer in parts of Colorado, Kansas, Nebraska, New Mexico, Oklahoma, South Dakota, Texas, and Wyoming: U.S. Geological Survey Open-File Report 98-393, accessed November 16, 2017, at

https://catalog.data.gov/dataset/digital-map-of-base-of-aquifer-for-high-plains-aquifer-in-parts-of-colorado-kansas-nebraska-new.

Conlon, T.D., Wozniak, K.C., Woodcock, D., Herrera, N.B., Fisher, B.J., Morgan, D.S., Lee, K.K., and Hinkle, S.R., 2005, Ground-water hydrology of the Willamette Basin, Oregon: U.S. Geological Survey Scientific Investigations Report 2005-5168, $83 \mathrm{p}$.

Eungard, D.W., 2014, Models of bedrock elevation and unconsolidated sediment thickness in the Puget Lowland, Washington: Washington Division of Geology and Earth Resources Open File Report 2014-04, 26 p.

Exxon Production Research Company, 1985, Tectonic map of the world: Houston, Tex., Exxon Production Research Company, 17 sheets.

Faunt, C.C., ed., 2009, Groundwater availability of the Central Valley Aquifer, California: U.S. Geological Survey Professional Paper 1766, 225 p.

Frezon, S.I., Finn, T.M., and Lister, J.H., comps., 1983, Total thickness of sedimentary rocks in the conterminous United States: U.S. Geological Survey Open-File Report 83-920, 1 pl.

Grauch, V.J.S., and Connell, S.D., 2013, New perspectives on the geometry of the Albuquerque Basin, Rio Grande Rift, New Mexico-Insights from geophysical models of rift-fill thickness, in Hudson, M.R., and Grauch, V.J.S., eds., New perspectives on Rio Grande Rift basins-From tectonics to groundwater: Geological Society of America Special Paper 494, p. 427-462, accessed October 2017 at https://doi.org/10.1130/2013.2494(16).

Gutentag, E.D., Heimes, F.J., Krothe, N.C., Luckey, R.R., and Weeks, J.B., 1984, Geohydrology of the High Plains Aquifer in parts of Colorado, Kansas, Nebraska, New Mexico, Oklahoma, South Dakota, Texas, and Wyoming: U.S. Geological Survey Professional Paper 1400-B, 63 p. 
Heywood, C.E., 2002, Estimation of alluvial-fill thickness in the Mimbres Ground-Water Basin, New Mexico, from interpretation of isostatic residual gravity anomalies: U.S. Geological Survey Water-Resources Investigations Report 02-4007, 21 p.

Heywood, C.E., and Yager, R.M., 2002, Simulated ground-water flow in the Hueco Bolson, an alluvial-basin aquifer system near El Paso, Texas: U.S. Geological Survey Water-Resources Investigations Report 02-4108, 80 p.

Houston, N.A., Gonzales-Bradford, S.L., and Flynn, A.T., 2013, Locations of wells and well log records used to develop the base of the northern High Plains aquifer underlying parts of Colorado, Kansas, Nebraska, South Dakota, and Wyoming, in Houston, N.A., Gonzales-Bradford, S.L., Flynn, A.T., Qi, S.L., Peterson, S.M., Stanton, J.S., Ryter, D.W., Sohl, T.L., and Senay, G.B., eds., Geodatabase compilation of hydrogeologic, remote sensing, and water-budget-component data for the High Plains Aquifer, 2011: U.S. Geological Survey Data Series 777, 12 p., accessed November 2017 at https://pubs.usgs.gov/ds/777/.

Jachens, R.C., and Moring, B.C., 1990, Maps of the thickness of Cenozoic deposits and the isostatic residual gravity over basement for Nevada: U.S. Geological Survey Open-File Report 90-404, 15 p.

Keller, G.R., Cordell, L., Davis, G.H., Peeples, W.J., and White, G., 1984, A geophysical study of the San Luis Basin, in Baldridge, W.S., Dickerson, P.W., Riecker, R.E., and Zidek, J., eds., Rio Grande rift—Northern New Mexico: New Mexico Geological Society, Fall Field Conference Guidebook 35, p. 51-57.

Langenheim, V.E., Graymer, R.W., Jachens, R.C., McLaughlin, R.J., Wagner, D.L., and Sweetkind, D.S., 2010, Geophysical framework of the northern San Francisco Bay region, California: Geosphere, v. 6, no. 5, p. 594-620.

Lovely, P., Shaw, J.H., Liu, Q., and Tromp, J., 2006, A structural V $\mathrm{p}_{\mathrm{p}}$ model of the Salton Trough, California, and its implications for seismic hazard: Bulletin of the Seismological Society of America, v. 96, no. 5, p. 1882-1896.

Ludington, S., Moring, B.C., Miller, R.J., Stone, P.A., Bookstrom, A.A., Bedford, D.R., Evans, J.G., Haxel, G.A., Nutt, C.J., Flyn, K.S., and Hopkins, M.J., 2007, Preliminary integrated geologic map databases for the United States-Western StatesCalifornia, Nevada, Arizona, Washington, Oregon, Idaho, and Utah (ver. 1.3, December 2007): U.S. Geological Survey OpenFile Report 2005-1305, accessed March 2016 at https://mrdata.usgs.gov/geology/state.

Marshak, S., Domrois, S., Abert, C., Larson, T., Pavlis, G., Hamburger, M., Yang, X., Gilbert, H., and Chen, C., 2017, The basement revealed-Tectonic insight from a digital elevation model of the great unconformity, USA cratonic platform: Geology, v. 45 , no. 5 , p. 391-394.

McCafferty, A., Bankey, V., and Brenner, K.C., 1998, Montana aeromagnetic and gravity maps and data: U.S. Geological Survey Open-File Report 98-333, accessed October 1998 at https://pubs.usgs.gov/of/1998/ofr-98-0333/mt.html.

McPhee, D.K., Langenheim, V.E., Wells, R.E., and Blakely, R.J., 2014, Tectonic evolution of the Tualatin basin, northwest Oregon, as revealed by inversion of gravity data: Geosphere, v. 10, no. 2, p. 264-275.

Mooney, W.D., and Kaban, M.K., 2010, The North American upper mantle-Density, composition, and evolution: Journal of Geophysical Research, v. 115, article no. B12424, 24 p., accessed February 2015 at https://doi.org/10.1029/2010JB000866.

National Oceanic and Atmospheric Administration, 1998, Idaho State gravity data: National Oceanic and Atmospheric Administration database, accessed January 1998 at https:/www.ngdc.noaa.gov/mgg/gravity/1999/data/regional/eros/idaho.

Pelletier, J.D., Broxton, P.D., Hazenberg, P., Zeng, X., Troch, P.A., Niu, G.-Y., Williams, Z., Brunke, M.A., and Gochis, D., 2016, A gridded global data set of soil, intact regolith, and sedimentary deposit thicknesses for regional and global land surface modeling: Journal of Advances in Modeling Earth Systems, v. 8, p. 41-65, accessed June 2016 at https://doi.org/10.1002/2015MS000526.

Radkins, H.C., Murphy, M., and Schuster, G.T., 1989, Subsurface map and seismic risk analysis of the Salt Lake Valley: Utah Geological and Mineral Survey Open-File Report 152, 82 p., 4 pls.

Saltus, R.W., 1993, Upper-crustal structure beneath the Columbia River Basalt Group, Washington - Gravity interpretation controlled by borehole and seismic studies: Geological Society of America Bulletin, v. 105, p. 1247-1259.

Saltus, R.W., and Jachens, R.C., 1995, Gravity and basin-depth maps of the Basin and Range Province, western United States: U.S. Geological Survey Map GP-1012, 1 pl.

Shah, A., and Boyd, O., 2018, Thickness of unconsolidated sediments for the western United States-Data files of the U.S. Geological Survey National Crustal Model: U.S. Geological Survey data release, https://doi.org/10.5066/P9Z6RC5L. 
Shah, A., Langenheim, V., and Boyd, O., 2018, Depth to Mesozoic basement for the western United States-Data files of the U.S. Geological Survey National Crustal Model: U.S. Geological Survey data release, https://doi.org/10.5066/P9X5ZX6Y.

Simpson, R.W., Jachens, R.C., and Blakely, R.J., 1986, A new isostatic residual gravity map of the conterminous United States with a discussion on the significance of isostatic residual anomalies: Journal of Geophysical Research, v. 91, p. 8348-8372. [Also available at https://doi.org/10.1029/JB091iB08p08348.]

Soller, D.R., and Garrity, C.P., 2018, Quaternary sediment thickness and bedrock topography of the glaciated United States east of the Rocky Mountains: U.S. Geological Survey Scientific Investigations Map 3392, 2 sheets, scale 1:5,000,000, accessed January 2018 at https://doi.org/10.3133/sim3392.

Stoeser, D.B., Green, G.N., Morath, L.C., Heran, W.D., Wilson, A.B., Moore, D.W., and Van Gosen, B.S., 2007, Preliminary integrated geologic map databases for the United States, Central States-Montana, Wyoming, Colorado, New Mexico, North Dakota, South Dakota, Nebraska, Kansas, Oklahoma, Texas, Iowa, Missouri, Arkansas, and Louisiana (ver. 1.2, December 2007): U.S. Geological Survey Open-File Report 2005-1351, accessed March 2016 at https://mrdata.usgs.gov/geology/state.

University of Texas at El Paso Regional Geospatial Service Center, 2016, U.S. gravity database: University of Texas at El Paso, Regional Geospatial Service Center, accessed June 2016 at http://gis.utep.edu.

Whittaker, J., Goncharov, A., Williams, S., Müller, R.D., Leitchenkov, G., 2013, Global sediment thickness dataset updated for the Australian-Antarctic Southern Ocean: Geochemistry, Geophysics, Geosystems, v. 14, no. 8, p. 3297-3305, accessed January 2017 at https://doi.org/10.1002/ggge.20181.

Williamson, A.K., Prudic, D.E., and Swain, L.A., 1989, Ground-water flow in the Central Valley, California: U.S. Geological Survey Professional Paper 1401-D, 127 p. 


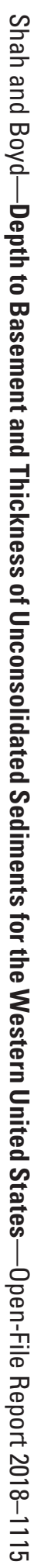

